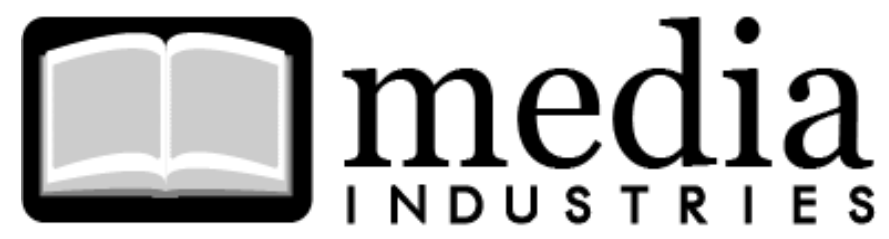

\title{
Book Review: Independent Stardom: Freelance Women in the Hollywood Studio System
}

Carman, Emily

Austin: University of Texas Press, 2016.

\section{Vicki Mayer ${ }^{1}$}

Tulane University

vmayer [AT] tulane.edu

In the not-so-distant future, corporate research firms estimate that 40-percent of the U.S. labor economy will be composed of freelancers, contractors, and temp workers, with women leading the way to what they pithily call the "she-conomy." 2 This should not be surprising. For while it has been long prophesized that the U.S. economy would become more networked like Hollywood studios, ${ }^{3}$ Emily Carman informs us that the first Hollywood freelancers were women.

Through a close read of the working contracts and their surrounding publicity for approximately a dozen starlets in the 1930s, Carman demonstrates how women worked as independent contractors at least a decade before the practice became commonplace. That is, she argues women had more agency during an era when the female audience required the cultivation of an "Alist" for star billings. Whereas many male stars submitted to the strict rules of single-studio contracts, a few women-Carole Lombard, Irene Dunn, and Barbara Stanwyck, to name a few-managed to
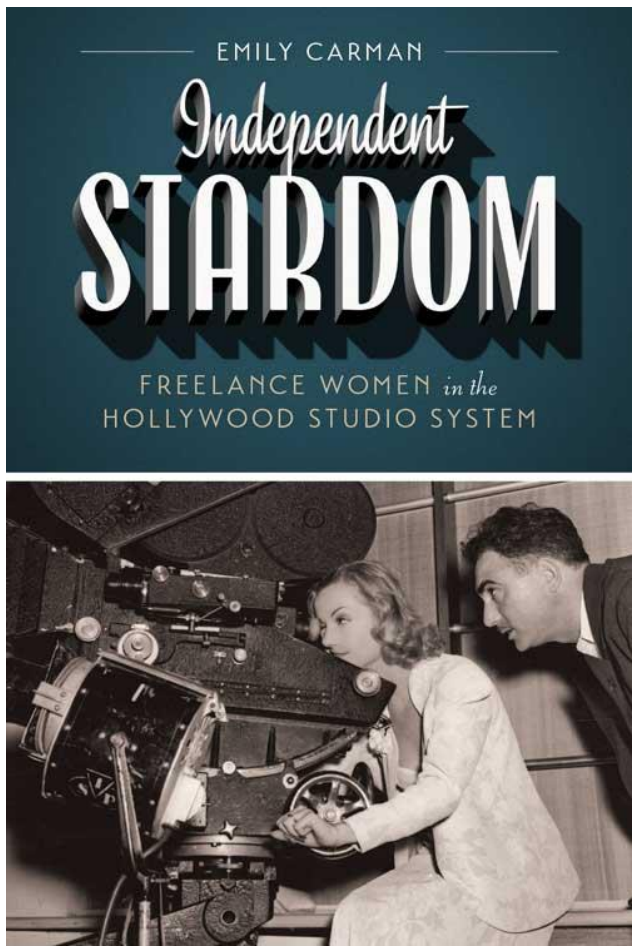
negotiate side deals, grab residual profits, and take more creative license with their images, including behind the camera and through publicity campaigns. Carman writes that their presence, while not the norm for creative labor in Hollywood, challenges film scholars' depictions of the era, which "negatively emphasize the 'capitalist' nature of the studio system with its patriarchal moguls and their supposed domination of women." 4

Carman's definition of "independence" involves two vectors: money and control. Independent stars got a guaranteed cut of the profits and called the shots on creative aspects of the job, from 
the script roles to the screen images. "Semi-independent" stars had only one of these benefits, sacrificing pay or creative power. "Dependent" stars had neither of these, although Carman shows that dependent stars such as Bette Davis actually could surpass the independent star both in recognition and pay raises.

This seemingly progressive continuum from the dependent to the independent with the normative judgment that independent is better begs several questions around the relationship between gender identity and a progressive politics of labor in media industries. Should we tout the fact that a few women paved the way for "an actor's right to the highest salary possible contingent upon his or her market value" ?5 Or should we celebrate these women as symbols of modernity with their achievement of "hybrid public celebrity as independent, working, 'modern' women"?

While I cannot comment on the silliness of the perception that women were purely victims of the classical Hollywood studio system, I am not completely satisfied by Carman's counter that this handful of stars either shows the positive nature of the studio system or shows perhaps that the system exceeded its capitalist aims through something that could be considered "notpatriarchal." Carman never uses the word "feminist" in her book, but the words "savvy" and "shrewd" peppered throughout its pages suggest that these women are role models for the new Hollywood economy. She asserts, "The Hollywood studio system can and should be reimagined as a production culture in which female stars excelled alongside other creativeminded actors, studio moguls, and producers." 7 To this assertion, I might add some caveats about imagining a production culture that seems to celebrate a few savvy and shrewd creative innovators at the expense of the rest of the workforce.

In short, every time period in U.S. media industry history might show the triumph of a few to the exclusion of many others. A critical read of Carman's work shows the power of meritocracy as an off-screen narrative in Hollywood. The rise of an independent gendered stardom in the 1930s could be seen as a prelude to a star culture disconnected from either the Screen Actors Guild as well as other employer-employee clusters in the industry. The stars' economic achievements were highly individuated and thus rather short-lived. Profit-sharing, for example, never extended beyond those above-the-line workers, and residuals from the films were part of actors' elaborate schemes to avoid paying income tax by claiming them as fixed-rate "capital gains." Eventually, it would become clear that the stars' independence was highly dependent on capitalist norms: namely the reification and the flexibilization of labor. The studios could shed their financial obligations through image markets that workers managed themselves. Meanwhile those image markets, organized around the capture of an imagined audience commodity, dictated the rules for market entry and activities.

By these logics, Carman's revelations about the careers of nonwhite female stars during the same period are more illuminating in forecasting the future of most freelance work in Hollywood. Stars such as Lupe Velez and Anna May Wong were independent contractors by necessity because the studios saw them as more expendable investments. Their short-term, project-based contracts more closely paralleled those penned in Poverty Row at the time, as well as the majority of those forged after the 1948 Paramount Decision forced the divestment of the studio system. What for Carman was the "only viable form of empowerment" for actresses of color $^{8}$ is now mainstream as above-the-line workers struggle to prove their worth with each project for an increasingly elusive audience segment. 
Perhaps it is worth remembering the etymology of the words "free lancer" which developed in the nineteenth century to refer to medieval mercenaries. The freelancing women in Carman's book are smart, brave, and strong, but they are also merciless in fending for themselves over their competitors. It is saddening that even just before the apex for American organized labor, we see so little in the way of solidarity among those working their way up. Carman notes in the end that in fact all independent workers are still dependent on their employers, a truism worth remembering when everyone wants to be the independent star.

In conclusion, Carman's work is important, not only as an alternative history of Hollywood labor, but also as guide for working on workers in early cinema. She generously gives readers tips for looking up documents, from payroll ledgers to contract summaries, in a variety of archives around the U.S. The book's appendix charts in fastidious detail the deals that each artist made during the time period she studied. This is a very useful resource guide to the archival texts. As for the archives, it is unfortunate that the University of California at Los Angeles, the University of Wisconsin, and the University of Texas have been unable thus far to digitize these materials for public dissemination. Carman's effort shows the potential for further mining of the labor conditions through which we have a "movie-made America." 9

${ }^{1}$ Vicki Mayer is Professor of Communication at Tulane University. She is author or editor of four books and numerous other publications about media production. She edits the journal Television $\mathcal{E}$ New Media (SAGE Publications) and directs the digital humanities project MediaNOLA. This piece is drawn from her most recent work on the cultural impacts of runaway film economies.

2 “The 2020 Intuit Report," Intuit, accessed May 31, 2016.

3 Jeremy Rifkin, The Age of Access: The New Culture of Hypercapitalism, Where All of Life is a Paid-for Experience (London: Tarcher, 2000), 24-8.

4 Emily Carman, Independent Stardom, 144.

5 Ibid., 136.

${ }^{6}$ Ibid., 95.

7 Ibid., 144.

8 Ibid., 91.

${ }^{9}$ From the title Robert Sklar, Movie-Made America: A Cultural History of American Movies (New York: Knoff/Doubleday, 1975).

\section{Bibliography:}

Intuit. “The 2020 Intuit Report." 2010. Accessed May 31, 2016.

Rifkin, Jeremy. The Age of Access: The New Culture of Hypercapitalism, Where All of Life is a Paid-for Experience. London: Tarcher, 2000.

Sklar, Robert. Movie-Made America: A Cultural History of American Movies. New York: Knoff/Doubleday, 1975. 
Media Industries Journal 3.1 (2016), ISSN: 2373-9037

\section{(cc) EY-NG-ND}

Copyright (C) 2016 (Vicki Mayer). Media Industries is an open-access, peer-reviewed, online academic journal. As such, we aim to participate in the open exchange of information. This work is licensed under a Creative Commons Attribution Noncommercial No Derivatives (by-nc-nd) License. Under this license, this work is available for sharing and noncommercial distribution provided the appropriate attribution is given. 